AGNIESZKA WolNA-MARUWKA ${ }^{1}$, AGNIESZKA MOCEK-PŁóCINIAK ${ }^{1}$, ANita SCHROETER-ZaKRZEWSKA ${ }^{2}$, ALICJA NiEWIADOMSKA ${ }^{1}$, TOMASZ PIECHOTA ${ }^{3}$, DOROTA SwĘDRZYŃSKA ${ }^{1}$, DONATA KOSICKA ${ }^{1}$, AGNIESZKa ANNA PILARSKA ${ }^{4}$

\author{
${ }^{1}$ Department of General and Environmental Microbiology \\ Poznań University of Life Sciences \\ ${ }^{2}$ Department of Ornamental Plants \\ Poznań University of Life Sciences \\ ${ }^{3}$ Department of Agronomy \\ Poznań University of Life Sciences \\ ${ }^{4}$ Institute of Food Technology of Plant Origin \\ Poznań University of Life Sciences
}

\title{
THE INFLUENCE OF A MICROBIAL INOCULUM ON THE ENZYMATIC ACTIVITY OF PEAT AND MORPHOLOGICAL FEATURES OF THE FRENCH MARIGOLD*
}

\author{
WPŁYW PREPARATU MIKROBIOLOGICZNEGO \\ NA AKTYWNOŚĆ ENZYMATYCZNĄ TORFU I CECHY MORFOLOGICZNE \\ AKSAMITKI ROZPIERZCHŁEJ
}

\begin{abstract}
Summary. The objective of the study was to determine the dynamics of the enzymatic activity in a substrate containing a microbiological inoculum (Effective Microorganisms - EM) intended to improve French marigold growth and flowering. The material used in the study was peat substrate of 5.5-6.0 pH into which plants were planted and then inoculated with different doses of the EM biofertilizer $(1: 10,1: 50,1: 100)$. Samples of the substrate on which experimental plants were cultivated were collected during the following three phases: the phase of seedling planting, the phase of vegetative growth and the phase of flowering. The scope of investigations comprised determination of the activity of dehydrogenases, urease and acid phosphatase activity by the spectrophotometric method. In addition, the following plant morphological analyses were performed: plant height, shoot number and length, number of buds and inflorescences, and leaf greenness index (SPAD). It was found that the phase of plant development was proved to be the main determinant of the activity of the enzymes under study. The EM biofertilizer had positive
\end{abstract}

*The study was supported by NCN (National Science Centre) grant no. N N305 036140. 
Wolna-Maruwka, A., Mocek-Płóciniak, A., Schroeter-Zakrzewska, A., Niewiadomska, A., Piechota, T., Swędrzyńska, D., Kosicka, D., Pilarska, A. A. (2015). The influence of a microbial inoculum on the enzymatic activity of peat and morphological features of the French marigold. Nauka Przyr. Technol., 9, 4, \#47. DOI: 10.17306/J.NPT.2015.4.47

effect on the acid phosphatase activity. However, the preparation did not have stimulating effect on the activity of urease or dehydrogenases. The EM biofertilizer concentrated at $1: 100$ and applied into the soil and foliage resulted in a larger number of darker leaves and greater number of inflorescences on the plants.

Key words: enzymatic activity, peat, biofertilizer EM, French marigold

\section{Introduction}

At present the introduction of the system of sustainable agriculture is thought to be a solution to the problem of excessive use of chemicals in conventional agriculture. On 1 January 2014 the EU member-states, including Poland, introduced obligatory integrated plant protection. In Poland it was introduced as a Regulation issued by the Minister of Agriculture and Rural Development. According to the principles of integrated plant protection specified in Annex III to Directive 2009/128/EC, "Sustainable biological, physical and other non-chemical methods must be preferred to chemical methods if they provide satisfactory pest control" (Pruszyński et al., 2012).

Microbial preparations are an alternative to chemical plant protection. At present there is high interest in preparations marked with the EM symbol (Effective Microorganisms), which are available on the market. They are meant to be used for plant growing both in agriculture and horticulture.

According to Mau (2007), the EM preparation is composed of lactic bacteria (Lactobacillus casei, Streptococcus lactis), photosynthetic bacteria (Rhodopseudomonas palustrus, Rhodobacter spae), yeasts (Saccharomyces albus, Candida utilis), actinobacteria (Streptomyces albus, S. griseus) and molds (Aspergillus oryzae, Mucor hiemalis). According to this author, Effective Microorganisms secrete vitamins, organic acids, amino acids and antioxidant substances and thus, they stimulate plant growth and exhibit phytosanitary properties. Janas (2009) and Wielgosz et al. (2010) also express the opinion that in agricultural and horticultural practice the combined effect of different groups of microorganisms which the EM is composed of has favourable effect on soil fertility. The microorganisms improve the conditions of plant development, because they facilitate the uptake of nutrients, support the plant growth, stimulate the development of seedlings through the production of hormonal substances, prevent the development of plant pathogens and gradually rebuild the substrate.

As results from the studies by Klama et al. (2010) and Wielgosz et al. (2010), the EM preparation has positive influence on the growth of wheat, rapeseed and barley. Faltyn and Miszkieło (2008) proved the positive effect of this preparation on the germination capacity of spring wheat seeds. As results from the research by Janas and Grzesik (2011), the EM biofertilizer accelerates the ripening of evening primrose seeds. There is not much information about the application of natural preparations in the cultivation of ornamental plants. The research by Wolna-Maruwka et al. (2010) proved that the EM biofertilizer applied in the cultivation of zonal geraniums accelerated the florescence of these plants and increased the number of buds and flowers on them. The studies on roses (Rosa $\times$ hybrida) and Barberton daisies (Gerbera jamesonii), which were conduc- 
Wolna-Maruwka, A., Mocek-Płóciniak, A., Schroeter-Zakrzewska, A., Niewiadomska, A., Piechota, T., Swędrzyńska, D., Kosicka, D., Pilarska, A. A. (2015). The influence of a microbial inoculum on the enzymatic activity of peat and morphological features of the French marigold. Nauka Przyr. Technol., 9, 4, \#47. DOI: 10.17306/J.NPT.2015.4.47

ted by Górski and Kleiber (2010), indicated that there was a greater number of flowers in both species and their diameters were larger.

According to Martyniuk (2010), there are some doubts about the effectiveness of most biopreparations available on the market, including the EM biofertilizer used for plant protection. The author justifies his doubts with the fact that it is very easy to register these preparations and there is no procedure requiring numerous and detailed investigations to confirm the effectiveness of the product. According to this author, the EM biofertilizer does not meet most requirements. For example, there is no detailed information about the composition of the inoculum; there are no scientific studies describing the techniques of identification of microorganisms in the biofertilizer; there are no findings confirming the usefulness and effectiveness of the product for plant protection.

In view of the fact that scientists express controversial opinions about the wide spectrum of use of the EM biofertilizer and due to the fact that the manufacturer declares a wide range of positive effects resulting from the application of this vaccine for plant protection, the aim of this study was to assess the influence of the EM biofertilizer on the enzymatic parameters of a peat substrate and morphological traits of the French marigold.

An investigation of the biochemical activity in the substrate will enable assessment which of the applied doses of the inoculum will contribute to significant changes in the enzymatic activity in the substrate. It will also enable assessment of the relationship between the dynamics of changes and the growth and development of French marigold.

\section{Material and methods}

The experiment was established in 2011 in a greenhouse in Marcelin, which belongs to the Department of Ornamental Plants of Poznan University of Life Sciences.

The material used in the experiment was peat substrate of 5.5-6.0 $\mathrm{pH}$, which was supplemented with a multicomponent fertilizer Osmocote Standard 5-6 M of slow action in the amount of $3 \mathrm{~g} \cdot \mathrm{dm}^{-3}$. Fertilizer Osmocote Standard 5-6 M contains macroelements such as: $15 \% \mathrm{~N}\left(6.6 \% \mathrm{NO}_{3}, 8.4 \% \mathrm{NH}_{4}\right), 9 \% \mathrm{P}_{2} \mathrm{O}_{5}, 12 \% \mathrm{~K}_{2} \mathrm{O}, 2 \% \mathrm{MgO}$, $0.45 \% \mathrm{Fe}$ and microelements: $0.06 \% \mathrm{Mn}, 0.03 \% \mathrm{~B}, 0.050 \% \mathrm{Cu}, 0.020 \% \mathrm{Mo}, 0.015 \% \mathrm{Zn}$.

Seedlings of French marigold were planted into pots of $12 \mathrm{~cm}$ diameter containing the above-mentioned substrate. The plants were inoculated with different doses of the Effective Microorganisms biofertilizer, which was applied either onto leaves or into the soil. The microbiological inoculum used in the study came from Greenland Technology EM.

The biofertilizer was diluted in tap water to obtain the following concentrations: $1: 10,1: 50$, and $1: 100$. The above-mentioned experimental inoculum was applied in two ways: onto leaves and into the soil but always in the amount of $10 \mathrm{ml}$. The experiment consisted of the combinations (each in ten replications) which are presented in Table 1.

The methodological assumptions adopted in the research used the current developmental phase of French marigold as the main factor determining the moment of collection of substrate samples: date I - seedling phase (beginning of the experiment), date II - phase of vegetative growth (after 33 days), and date III - phase of plant flowering (after 50 days). 
Wolna-Maruwka, A., Mocek-Płóciniak, A., Schroeter-Zakrzewska, A., Niewiadomska, A., Piechota, T., Swędrzyńska, D., Kosicka, D., Pilarska, A. A. (2015). The influence of a microbial inoculum on the enzymatic activity of peat and morphological features of the French marigold. Nauka Przyr. Technol., 9, 4, \#47. DOI: 10.17306/J.NPT.2015.4.47

Table 1. Experimental combinations

Tabela 1. Kombinacje doświadczalne

\begin{tabular}{|c|c|}
\hline $\begin{array}{l}\text { Combination } \\
\text { Kombinacja }\end{array}$ & $\begin{array}{l}\text { Composition } \\
\text { Skład }\end{array}$ \\
\hline $\mathrm{K}$ & $\begin{array}{l}\text { Peat }+ \text { plant } \\
\text { Torf }+ \text { roślina }\end{array}$ \\
\hline K1 & $\begin{array}{l}\text { Peat }+ \text { plant }+ \text { watering with the preparation }-1: 10 \\
\text { Torf }+ \text { roślina }+ \text { podlewanie preparatem }-1: 10\end{array}$ \\
\hline $\mathrm{K} 2$ & $\begin{array}{l}\text { Peat }+ \text { plant }+ \text { watering with the preparation }-1: 50 \\
\text { Torf }+ \text { roślina }+ \text { podlewanie preparatem }-1: 50\end{array}$ \\
\hline K3 & $\begin{array}{l}\text { Peat }+ \text { plant }+ \text { watering with the preparation }-1: 100 \\
\text { Torf }+ \text { roślina }+ \text { podlewanie preparatem }-1: 100\end{array}$ \\
\hline K4 & $\begin{array}{l}\text { Peat }+ \text { plant }+ \text { spraying with the preparation }-1: 10 \\
\text { Torf }+ \text { roślina }+ \text { opryskiwanie preparatem }-1: 10\end{array}$ \\
\hline K5 & $\begin{array}{l}\text { Peat }+ \text { plant }+ \text { spraying with the preparation }-1: 50 \\
\text { Torf }+ \text { roślina }+ \text { opryskiwanie preparatem }-1: 50\end{array}$ \\
\hline K6 & $\begin{array}{l}\text { Peat }+ \text { plant }+ \text { spraying with the preparation }-1: 100 \\
\text { Torf }+ \text { roślina }+ \text { opryskiwanie preparatem }-1: 100\end{array}$ \\
\hline K7 & $\begin{array}{l}\text { Peat }+ \text { plant }+ \text { watering and spraying with the preparation }-1: 10 \\
\text { Torf }+ \text { roślina }+ \text { podlewanie } \mathrm{i} \text { opryskiwanie preparatem }-1: 10\end{array}$ \\
\hline K8 & $\begin{array}{l}\text { Peat }+ \text { plant }+ \text { watering and spraying with the preparation }-1: 50 \\
\text { Torf }+ \text { roślina }+ \text { podlewanie i opryskiwanie preparatem }-1: 50\end{array}$ \\
\hline K9 & $\begin{array}{l}\text { Peat }+ \text { plant }+ \text { watering and spraying with the preparation }-1: 100 \\
\text { Torf }+ \text { roślina }+ \text { podlewanie } i \text { opryskiwanie preparatem }-1: 100\end{array}$ \\
\hline
\end{tabular}

Biochemical analyses were performed on the basis of the spectrophotometric method. Dehydrogenases activity was determined according to Thalmann (1968) with some minor modifications. Soil (1 g) was incubated for $24 \mathrm{~h}$ with 2,3,5-triphenyltetrazolium chloride (TTC) at $30^{\circ} \mathrm{C}, \mathrm{pH} 7.4$. The produced triphenylformazan (TPF) was extracted with $96 \%$ ethanol and measured spectrophotometrically at $485 \mathrm{~nm}$. Dehydrogenases activity was expressed as micromoles TPF per $1 \mathrm{~g}$ during $24 \mathrm{~h}$.

Soil urease activity was assayed as described by Hoffmann and Teicher (1961). Briefly, $1 \mathrm{~g}$ of moist soil was incubated with $0.15 \mathrm{ml}$ of toluene for $15 \mathrm{~min}$ at room temperature. Next $1 \mathrm{ml}$ of the urea solution was added to the soil samples and they were incubated for $18 \mathrm{~h}$ at a temperature of $37^{\circ} \mathrm{C}$. After the incubation $5 \mathrm{ml}$ of $0.03 \mathrm{M}$ acetic acid was added and shaken for $20 \mathrm{~min}$. Next the samples were drained through paper filters $(90 \mathrm{~mm})$, Munktell Ahlstrom firm. $0.4 \mathrm{ml}$ of $25 \%$ sodium potassium tartrate, 18 $\mathrm{ml}$ of distilled water and $0.4 \mathrm{ml}$ of Nessler's reagent were added. The wavelength urease activity was $410 \mathrm{~nm}$ and it was expressed as microgrammes $\mathrm{N}$ per $1 \mathrm{~g}$ during $18 \mathrm{~h}$.

The activity of acid phosphatase was assayed as described by Tabatabai and Bremner (1969). Briefly, $1 \mathrm{~g}$ of moist soil was incubated with $0.25 \mathrm{ml}$ of toluene for $15 \mathrm{~min}$ at room temperature. Next, $5 \mathrm{ml}$ of the buffer solution was added to the soil samples. The $\mathrm{pH}$ of the buffer solution was 6.5 and it contained p-nitrophenylophosphate sodium 
Wolna-Maruwka, A., Mocek-Płóciniak, A., Schroeter-Zakrzewska, A., Niewiadomska, A., Piechota, T., Swędrzyńska, D., Kosicka, D., Pilarska, A. A. (2015). The influence of a microbial inoculum on the enzymatic activity of peat and morphological features of the French marigold. Nauka Przyr. Technol., 9, 4, \#47. DOI: 10.17306/J.NPT.2015.4.47

substrate, which was solved in it. After the incubation $1 \mathrm{ml}$ of $0.5 \mathrm{M} \mathrm{CaCl}_{2}$ and $4 \mathrm{ml}$ of $0.5 \mathrm{M} \mathrm{NaOH}$ were added to all the test tubesin order to stop the reaction. Next, the solution was drained through paper filters Munktell Ahlstrom firm $(90 \mathrm{~mm})$ and the value was read on a spectrophotometer at a wavelength of $400 \mathrm{~nm}$. The enzyme activity was expressed as micromoles PNP per $1 \mathrm{~g}$ during $1 \mathrm{~h}$.

Measurements of the following traits were taken during the period of plant flowering: the height of the leaf floor, number of leaves, width and length of the leaf blade, as well as leaf greenness index (SPAD) with the assistance of the means of Yara N-Tester apparatus.

In addition, the percentage of dyed inflorescence buds, indicating the earliness of flowering, and the length of the inflorescence were assessed. Changes in the morphological traits of the French marigold and the enzymatic levels in consecutive developmental phases of scarlet sage were elaborated statistically with two-factorial analysis of variance. Moreover, Tukey's test and Least Significant Difference (LSD) test were also used and their results are presented graphically in order to facilitate interpretation of the obtained differences in the level of the parameters under study (Ott, 1984).

\section{Results and discussion}

According to Brzezińska and Włodarczyk (2005), the activity of dehydrogenases in the substrate is regarded as an indicator of the intensity of respiratory metabolism in microorganisms, mainly bacteria and actinobacteria. The analysis of the activity of these enzymes in a particular environment gives a possibility to draw conclusions about the content of organic matter or fertility of the substrate (Mocek-Płóciniak, 2010). Apart from that, the research by Brzezińska et al. (2001) points to a significant dependence between the biological activity of dehydrogenases and the substrate aeration parameters.

The phase of plant development was the main factor contributing to statistically significant changes in the dehydrogenases activity in the peat substrate under French marigolds (Fig. 1). Apart from the control combination, these enzymes exhibited the highest activity at the second term of the analyses (the phase of the vegetative growth of French marigolds). According to Wielgosz and Szember (2006), the plant root secretions during the intensive growth of plants may stimulate the dehydrogenases activity.

The increase in the dehydrogenases activity at the second term of the analyses may also have been caused by the application of the EM biofertilizer, because at the phase of the vegetative growth of French marigolds the dehydrogenases activity did not increase in the control combination only. We can suppose that the main cause of the increase in the dehydrogenases activity was the microorganisms which were entered into the substrate together with the inoculum.

At the inflorescence phase there was a decrease in the dehydrogenases activity in all of the experimental samples under analysis. It is most likely that the root secretions from the French marigolds were one of the main determinants of the level of dehydrogenases activity at that phase. Wolna-Maruwka et al. (2012) also observed an increase in the dehydrogenases activity in sage at the phase of vegetative growth, which was followed by a decrease in the activity at the inflorescence phase. 
Wolna-Maruwka, A., Mocek-Płóciniak, A., Schroeter-Zakrzewska, A., Niewiadomska, A., Piechota, T., Swędrzyńska, D., Kosicka, D., Pilarska, A. A. (2015). The influence of a microbial inoculum on the enzymatic activity of peat and morphological features of the French marigold. Nauka Przyr. Technol., 9, 4, \#47. DOI: 10.17306/J.NPT.2015.4.47

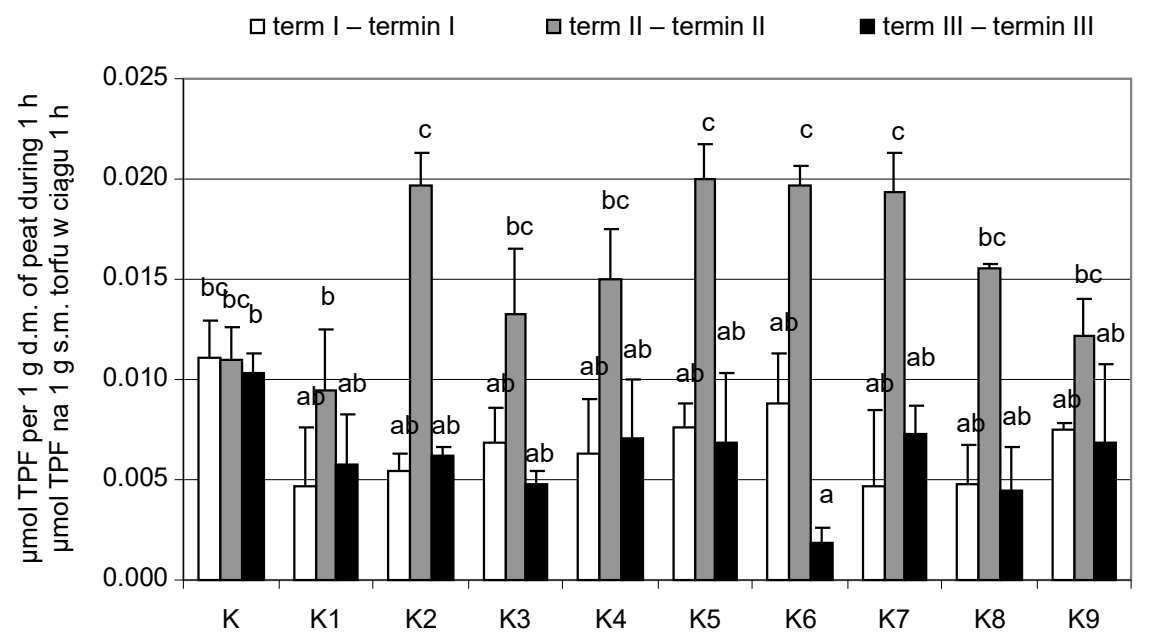

Fig. 1. Changes of the dehydrogenases activity; $\mathrm{K}-$ control, $\mathrm{K} 1$ - watering with the preparation 1 : $10, \mathrm{~K} 2$ - watering with the preparation $1: 50, \mathrm{~K} 3$ - watering with the preparation $1: 100, \mathrm{~K} 4$ - spraying with the preparation $1: 10, \mathrm{~K} 5$ - spraying with the preparation $1: 50, \mathrm{~K} 6$ - spraying with the preparation $1: 100, \mathrm{~K} 7$ - watering and spraying with the preparation $1: 10, \mathrm{~K} 8$ - watering and spraying with the preparation $1: 50, \mathrm{~K} 9$ watering and spraying with the preparation $1: 100$; means followed by the same letters do not differ statistically significantly at $\alpha=0.05$

Rys. 1. Zmiany aktywności dehydrogenaz; $\mathrm{K}$ - kontrola, $\mathrm{K} 1$ - podlewanie preparatem $1: 10$, $\mathrm{K} 2$ - podlewanie preparatem $1: 50, \mathrm{~K} 3$ - podlewanie preparatem $1: 100, \mathrm{~K} 4$ - opryskiwanie preparatem $1: 10, \mathrm{~K} 5$ - opryskiwanie preparatem $1: 50, \mathrm{~K} 6$ - opryskiwanie preparatem $1: 100, \mathrm{~K} 7$ - podlewanie i opryskiwanie preparatem $1: 10, \mathrm{~K} 8$ - podlewanie i opryskiwanie preparatem $1: 50, \mathrm{~K} 9$ - podlewanie $\mathrm{i}$ opryskiwanie preparatem $1: 100$; średnie oznaczone tymi samymi literami nie różnią się istotnie statystycznie przy $\alpha=0,05$

According to Kucharski and Niewolak (1997), the decrease in the enzymatic activity in the substrate also results from the decrease in the content of organic matter in the substrate. On the other hand, Januszek et al. (2007) report that the $\mathrm{pH}$ of the substrate has significant influence on the dehydrogenases activity. According to these authors, the dehydrogenases activity decreases as the $\mathrm{pH}$ of the substrate decreases. According to Brzezińska and Włodarczyk (2005), the activity of dehydrogenases is the greatest when $\mathrm{pH}$ is between 7 and 7.8 .

In our study the $\mathrm{pH}$ value increased at the French marigold inflorescence phase (the third term) (Fig. 2), so it could not have caused variation in the dehydrogenases activity. Therefore, we can suppose that apart from changes in the qualitative and quantitative composition of root secretions, the decrease in the enzymatic activity in the substrate may have been caused by a decrease in the content of degradable organic matter or the presence of products of microbiological transformations, which inhibited metabolic reactions.

The EM inoculum did not prove to have a significant effect on the dehydrogenases activity, regardless of the dose applied and the treatment type. The research by Kucharski 
Wolna-Maruwka, A., Mocek-Płóciniak, A., Schroeter-Zakrzewska, A., Niewiadomska, A., Piechota, T., Swędrzyńska, D., Kosicka, D., Pilarska, A. A. (2015). The influence of a microbial inoculum on the enzymatic activity of peat and morphological features of the French marigold. Nauka Przyr. Technol., 9, 4, \#47. DOI: 10.17306/J.NPT.2015.4.47

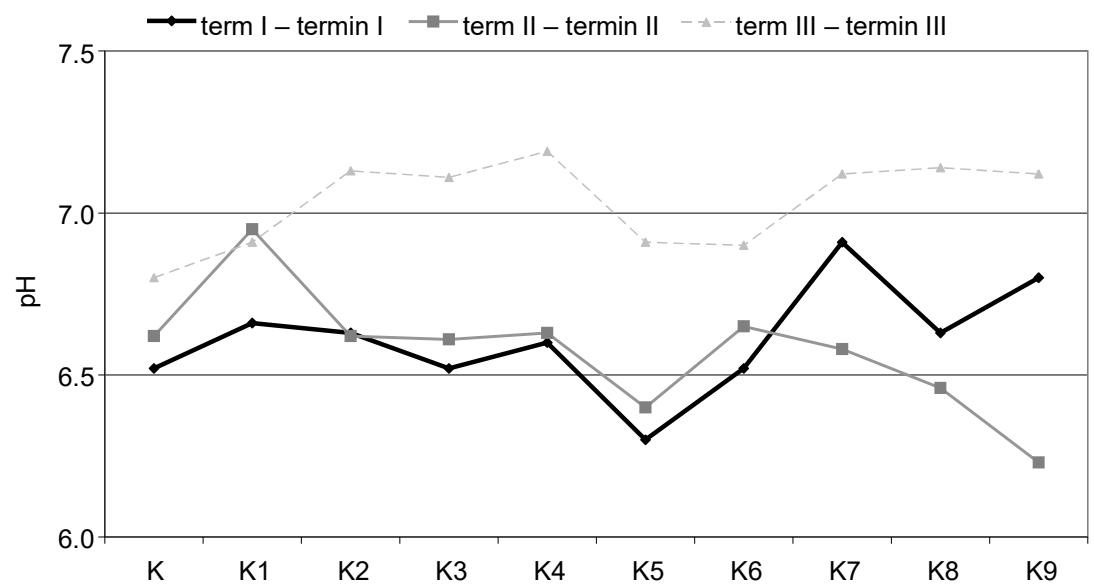

Fig. 2. Changes of the $\mathrm{pH}$ value; explanations - as in Figure 1

Rys. 2. Zmiany wartości pH; objaśnienia - jak na rysunku 1

and Jastrzębska (2005) also confirms the fact that the EM biofertilizer has no effect on the dehydrogenases activity in the soil. On the other hand, the study by Kaczmarek et al. (2008) proves that the preparation stimulates the activity of these enzymes.

The analysis of the mean biofertilizer decreased the urease activity regardless of the experimental combination (except sample K5 - peat substrate + plant + spraying $1: 50$ ). Ammonification is also one of the stages in the complex process of mineralisation of organic matter in the substrate. This chemical reaction is dependent upon deaminases, including urease. As a result of the urease activity, organic nitrogen compounds are transformed into mineral nitrogen, which can be easily absorbed by plants (Wyczółkowski and Dąbek-Szreniawska, 2005). The research findings (Fig. 3) prove that the highest level of the urease activity was observed at the French marigold inflorescence phase regardless of the experimental combination (the third term of analyses). It was probably caused by changes in the composition of the French marigold root secretions. This is proved by the fact that the urease activity also increased in the control sample.

As Vallance et al. (2011) claimed, root secretions contain organic compounds, which are rich in carbon. These secretions differ qualitatively and quantitatively depending on the plant species and cultivar, the stage of plant development and abiotic factors, such as light, $\mathrm{pH}$, substrate humidity and the content of nutrients in the substrate.

According to Kucharski (1997), it is not only microorganisms but also plants and soil fauna that are sources of enzymes. Higher plants directly and indirectly enrich the soil with enzymes. They directly supply enzymes to the soil from the dead aerial and underground parts of plants, whose cells undergo autolysis. The indirect influence consists in the stimulation of enzyme synthesis by the microorganisms degrading plant debris and root secretions.

The results of biochemical analyses shown in Figure 3 revealed that at the third term of the research the highest statistically significant enzymatic activity was observed in 
Wolna-Maruwka, A., Mocek-Płóciniak, A., Schroeter-Zakrzewska, A., Niewiadomska, A., Piechota, T., Swędrzyńska, D., Kosicka, D., Pilarska, A. A. (2015). The influence of a microbial inoculum on the enzymatic activity of peat and morphological features of the French marigold. Nauka Przyr. Technol., 9, 4, \#47. DOI: 10.17306/J.NPT.2015.4.47

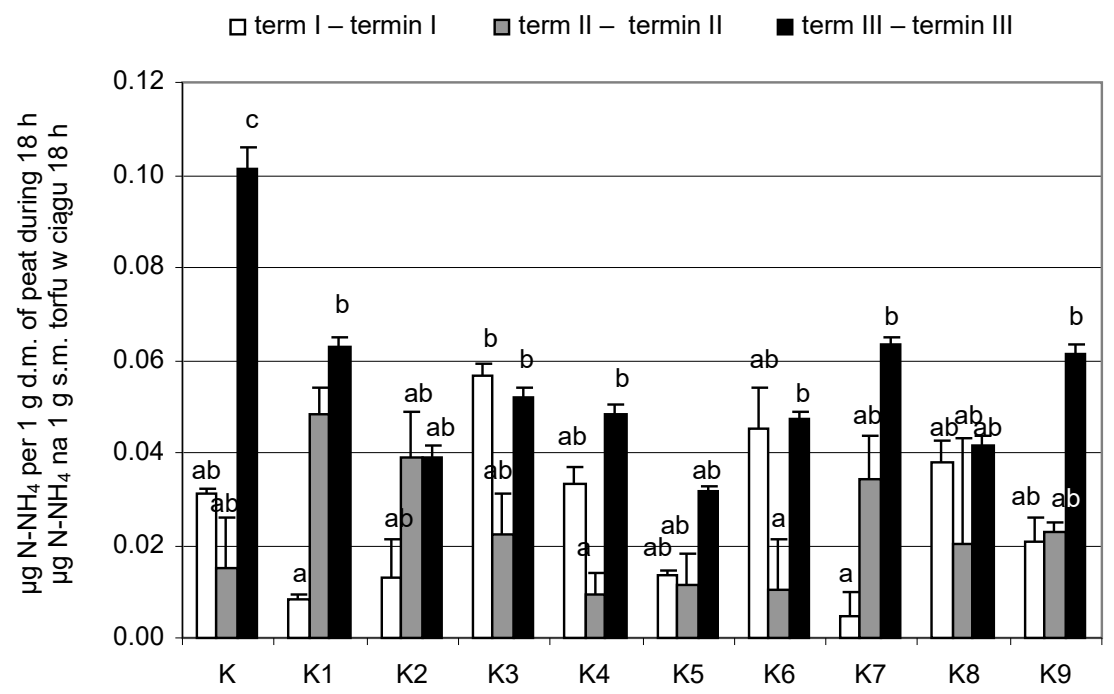

Fig. 3. Changes of the urease activity; explanations - as in Figure 1

Rys. 3. Zmiany aktywności ureazy; objaśnienia - jak na rysunku 1

the control sample. Guettes et al. (2002) also express the opinion that the inhibition of the urease activity in the soil is usually caused by the presence of some biotic factors reducing the population of autochthonous microorganisms in the environment, which affect the urease production. Apart from that, according to these authors, the urease activity level depends on the value of dry weight of the substrate.

Phosphatase also play an important role in the mineralisation of organic matter and supplying nutrients to plants (Gibczyńska and Lewandowska, 2005). These enzymes catalyse the disconnection of phosphate residue from organic compounds (carbohydrates, proteins, fats) and other phosphoric acid esters and thus, they enable plants and other organisms to use inorganic phosphorus in the form $\mathrm{H}_{2} \mathrm{PO}_{4}^{-}$and $\mathrm{HPO}_{4}^{2-}$ of anions (Tarafdar and Rao, 1990).

It is necessary to note the fact that apart from microorganisms, plants also have significant influence on the production and secretion of phosphatase into the environment (Żebrowska and Ciereszko, 2009). According to Schneider et al. (2001), the high concentration of acid phosphatase in the substrate means that there is a deficit of available phosphorus. Phosphatases are capable of hydrolysing phosphorus organic compounds in the amounts exceeding plants' demand for this element (Tarafdar and Rao, 1990).

The phase of plant development was the main factor causing statistically significant changes in the acid phosphatase activity in the peat substrate under French marigolds (Fig. 4). The highest level of the enzyme activity in all of the experimental samples was noted at the second term of the analyses (the phase of the vegetative growth of French marigolds). The phenomenon was probably caused by the root secretions of French marigolds. According to Bais et al. (2006), the qualitative and quantitative composition of the root secretions of French marigolds depends not only on the plant species but also 
Wolna-Maruwka, A., Mocek-Płóciniak, A., Schroeter-Zakrzewska, A., Niewiadomska, A., Piechota, T., Swędrzyńska, D., Kosicka, D., Pilarska, A. A. (2015). The influence of a microbial inoculum on the enzymatic activity of peat and morphological features of the French marigold. Nauka Przyr. Technol., 9, 4, \#47. DOI: 10.17306/J.NPT.2015.4.47

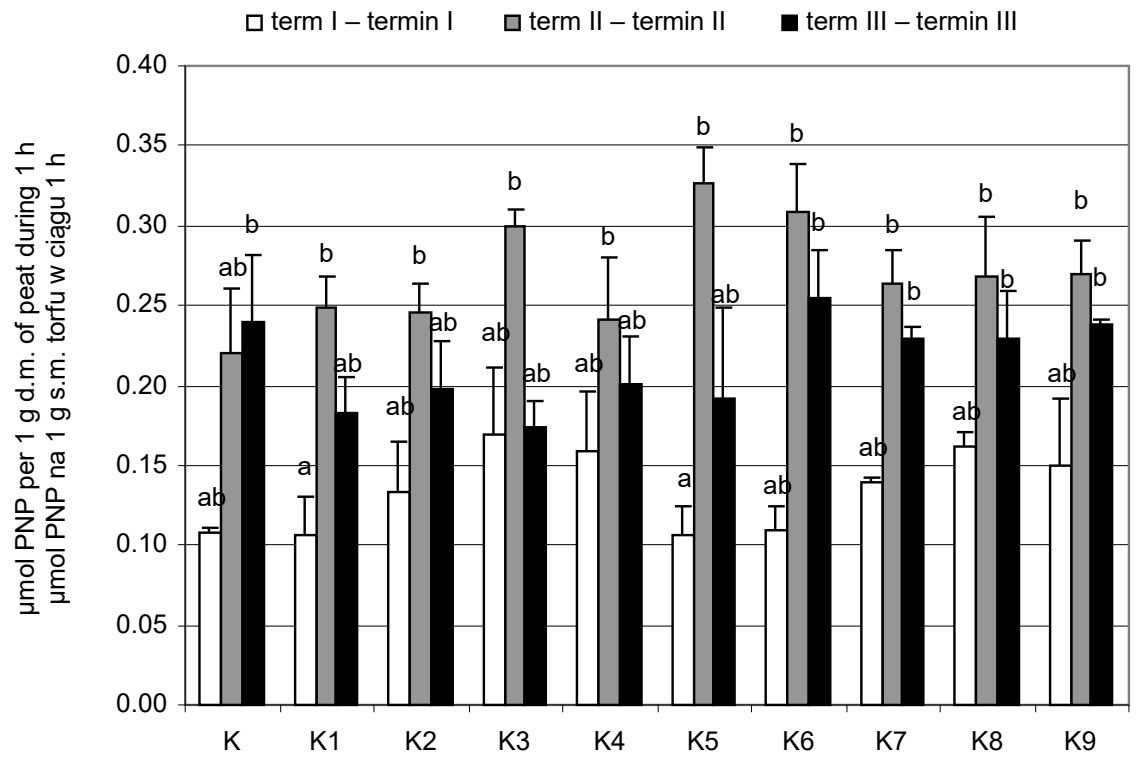

Fig. 4. Changes of the acid phosphatase activity; explanations - as in Figure 1

Rys. 4. Zmiany aktywności fosfatazy kwaśnej; objaśnienia - jak na rysunku 1

on the plant development stage. At the inflorescence phase (the third term of analyses) there was reduced phosphatase activity in all the combinations except the control sample. We can suppose that the reduced enzymatic activity at the inflorescence phase was caused by the influence of the EM inoculum.

The analysis of the influence of the vaccine on the acid phosphatase activity level revealed that the EM biofertilizer applied both to the soil and foliage caused an increase in the enzyme activity. However, in comparison with the control combination, this increase was not statistically significant. On the other hand, Bielińska et al. (2013) reported that the EM biofertilizer had negative influence on the phosphatase activity in the soil under triticale and on the stimulation of the urease and dehydrogenases activity. According to Martyniuk and Księżak (2011), differences in the results of the application of microbial preparations may have been caused by their poor quality, which may be even more reduced during their production.

The preparation applied in the study did not have influence on the plant growth. There were similar observations in the studies by Wolna-Maruwka et al. (2010) and Schroeter-Zakrzewska et al. (2013) after the application of the EM biofertilizer to zonal geraniums. Frąszczak et al. (2012) obtained different results for sweet basil, where the EM biofertilizer inhibited the plant growth.

It is not only the habit and abundance of inflorescence, but also the number of leaves and their colour that are decisive to the plant quality (Table 2). There were noticeable changes in the number of leaves as there were more leaves on the plants which had been treated with the EM microbial biofertilizer. The plants sprayed with the preparation dissolved in the proportion $1: 100$ were the only exception to the rule. In this case the 
Wolna-Maruwka, A., Mocek-Płóciniak, A., Schroeter-Zakrzewska, A., Niewiadomska, A., Piechota, T., Swędrzyńska, D., Kosicka, D., Pilarska, A. A. (2015). The influence of a microbial inoculum on the enzymatic activity of peat and morphological features of the French marigold. Nauka Przyr. Technol., 9, 4, \#47. DOI: 10.17306/J.NPT.2015.4.47

Table 2. Influence of EM biofertilizer on morphological parameters of French marigold Tabela 2. Wpływ preparatu EM na parametry morfologiczne aksamitki rozpierzchłej

\begin{tabular}{|c|c|c|c|c|c|c|c|c|c|c|}
\hline \multirow{2}{*}{$\begin{array}{l}\text { Feature } \\
\text { Cecha }\end{array}$} & \multicolumn{10}{|c|}{$\begin{array}{l}\text { Combinations } \\
\text { Kombinacje }\end{array}$} \\
\hline & K & K1 & K2 & K3 & K4 & K5 & K6 & K7 & K8 & K9 \\
\hline $\begin{array}{l}\text { Height of plant }(\mathrm{cm}) \\
\text { Wysokość rośliny } \\
(\mathrm{cm})\end{array}$ & $9.5 \mathrm{a}$ & $10.0 \mathrm{a}$ & $10.5 \mathrm{a}$ & $10.4 \mathrm{a}$ & $10.8 \mathrm{a}$ & $11.0 \mathrm{a}$ & $9.6 \mathrm{a}$ & 11.0a & $9.2 \mathrm{a}$ & $10.4 \mathrm{a}$ \\
\hline $\begin{array}{l}\text { Number of shoots } \\
\text { per plant } \\
\text { Liczba pędów na } \\
\text { roślinie }\end{array}$ & $10.8 \mathrm{a}$ & $12.4 \mathrm{ab}$ & $12.1 \mathrm{ab}$ & $13.3 \mathrm{c}$ & $12.1 \mathrm{ab}$ & $14.6 \mathrm{~d}$ & $12.1 \mathrm{ab}$ & 11.9ab & $11.7 \mathrm{ab}$ & $11.2 \mathrm{ab}$ \\
\hline $\begin{array}{l}\text { Number of leaves } \\
\text { per plant } \\
\text { Liczba liści na } \\
\text { roślinie }\end{array}$ & $38.7 \mathrm{a}$ & $40.8 \mathrm{ab}$ & $43.1 \mathrm{bc}$ & $43.7 \mathrm{bc}$ & $41.5 \mathrm{bc}$ & $40.0 \mathrm{ab}$ & $40.8 \mathrm{ab}$ & $38.5 \mathrm{a}$ & $45.5 \mathrm{de}$ & $50.7 \mathrm{f}$ \\
\hline $\begin{array}{l}\text { Greening index of } \\
\text { leaves (SPAD) } \\
\text { Indeks zazielenienia } \\
\text { (SPAD) }\end{array}$ & $49.4 a$ & $53.0 \mathrm{a}$ & $52.8 \mathrm{a}$ & $55.1 \mathrm{~b}$ & $53.4 \mathrm{a}$ & $53.23 \mathrm{a}$ & 49.1a & $52.7 \mathrm{a}$ & 47.6a & $55.3 \mathrm{~b}$ \\
\hline $\begin{array}{l}\text { Number of inflores- } \\
\text { cences per plant } \\
\text { Liczba kwiato- } \\
\text { stanów na roślinie }\end{array}$ & $1.0 \mathrm{a}$ & $2.0 \mathrm{~b}$ & $1.8 \mathrm{~b}$ & $2.0 \mathrm{~b}$ & $1.6 \mathrm{~b}$ & $1.4 \mathrm{a}$ & $2.0 \mathrm{~b}$ & $1.4 \mathrm{a}$ & $1.8 \mathrm{~b}$ & $2.3 \mathrm{c}$ \\
\hline $\begin{array}{l}\text { Length of inflores- } \\
\text { cences }(\mathrm{cm}) \\
\text { Długość kwiato- } \\
\text { stanów }(\mathrm{cm})\end{array}$ & $2.9 \mathrm{a}$ & $3.2 \mathrm{a}$ & $3.4 \mathrm{a}$ & $3.4 \mathrm{a}$ & $3.3 \mathrm{a}$ & $3.2 \mathrm{a}$ & $3.3 \mathrm{a}$ & $3.2 \mathrm{a}$ & $3.4 \mathrm{a}$ & $3.2 \mathrm{a}$ \\
\hline
\end{tabular}

Means followed by the same letters do not differ statistically significantly at $\alpha=0.05$.

Średnie oznaczone tymi samymi literami nie różnią się istotnie statystycznie przy $\alpha=0,05$.

number of leaves was statistically the same as in the control plants. The plants which were irrigated and sprayed with the EM biofertilizer dissolved in the proportion $1: 100$ produced particularly great numbers of leaves. The number of leaves was respectively $17.5 \%$ and $31 \%$ greater than in the control plants. The positive influence of Effective Microorganisms (EM) on the number of leaves was also reported by Khan et al. (2006). Wolna-Maruwka et al. (2014) obtained a greater number of leaves in the study on French marigolds when they applied another microbial inoculum, i.e. $\mathrm{BAF}_{1}$, but the proportions of the solution were the same as in this study.

This study did not reveal significant changes in the foliage colour. Only when the EM preparation was applied in a combination of solutions $1: 10$ and $1: 100$, the statistical analysis revealed that in comparison with other plants there were significant differences in the leaf greenness index, expressed in the SPAD unit. There are different opinions about the leaf colour, defined as the chlorophyll content or leaf greenness index 
Wolna-Maruwka, A., Mocek-Płóciniak, A., Schroeter-Zakrzewska, A., Niewiadomska, A., Piechota, T., Swędrzyńska, D., Kosicka, D., Pilarska, A. A. (2015). The influence of a microbial inoculum on the enzymatic activity of peat and morphological features of the French marigold. Nauka Przyr. Technol., 9, 4, \#47. DOI: 10.17306/J.NPT.2015.4.47

SPAD (Table 2). The literature provides information about the positive, neutral or negative influence of microbial vaccines applied in plant cultivation (Frąszczak et al., 2012; Khan et al., 2006; Wolna-Maruwka et al., 2010, 2012, 2014).

The French marigold is a basic species used for cultivation in flowerbeds in cities and in home gardens. The main advantage of these flowerbed plants is their long and abundant florescence. The positive effect of microbial vaccines on florescence was reported by Aytekin and Acikgoz (2008), Górski and Kleiber (2010), Schroeter-Zakrzewska et al. (2013), Wolna-Maruwka et al. (2012, 2014). A greater number of inflorescence buds developed on plants when the EM preparation was applied both into the foliage and soil in a solution concentrated at $1: 10$ and when it was applied into the soil in a solution concentrated at $1: 50$. All the plants treated with a solution of the EM biofertilizer had more abundant inflorescences. The only exception was the plants which had been irrigated with a solution of the EM preparation concentrated at 1:50 and sprayed with a solution concentrated at $1: 10$. They did not differ significantly from the control plants in the number of inflorescences.

The applied microbial vaccine had no influence on the diameter of French marigold inflorescences.

\section{Conclusions}

1. The phase of plant development was proved to be the main determinant of the activity of the enzymes under study.

2. Apart from the acid phosphatase activity the EM did not have stimulating effect on the enzymatic activity of the peat substrate under the plants in the experiment.

3 . The research proved that the EM inoculum had positive effect on the morphological features of French marigold when it was simultaneously applied into leaves and into the soil (diluted $1: 100)$.

4. Appropriate application and dose of the EM inoculum gives perspectives for its use in bedding plants.

\section{References}

Aytekin, A., Acikgoz, A. O. (2008). Hormone and microorganism treatments in the cultivation of saffron (Crocus sativus L.) plants. Molecules, 13, 5, 1135-1147.

Bais, H., Weir, T., Perry, L., Gilroy, S., Vivanco, J. (2006). The role of root exudates in rhizosphere interactions with plants and other organisms. Annu. Rev. Plant Biol., 57, 33-66.

Bielińska, E. J., Futa, B., Bik-Mołodzińska, M., Szewczuk, Cz., Sugier, D. (2013). Wpływ preparatów użyźniających na aktywność enzymatyczną gleb. J. Res. Appl. Agric. Eng., 58, 3, 15-19.

Brzezińska, M., Stępniewska, Z., Stępniewski, W., Włodarczyk, T., Przywara, G., Bennicelli, R. (2001). Effect of oxygen deficiency on soil dehydrogenases activity (pot experiment with barley). Int. Agrophys., 15, 3-7.

Brzezińska, M., Włodarczyk, T. (2005). Enzymy wewnątrzkomórkowych przemian redoks (oksydoreduktazy). Acta Agrophys. Rozpr. Monogr., 120, 3, 11-26. 
Wolna-Maruwka, A., Mocek-Płóciniak, A., Schroeter-Zakrzewska, A., Niewiadomska, A., Piechota, T., Swędrzyńska, D., Kosicka, D., Pilarska, A. A. (2015). The influence of a microbial inoculum on the enzymatic activity of peat and morphological features of the French marigold. Nauka Przyr. Technol., 9, 4, \#47. DOI: 10.17306/J.NPT.2015.4.47

Faltyn, U., Miszkieło, T. (2008). Wpływ efektywnych mikroorganizmów (EM®) na zdolność kiełkowania ziarna pszenicy jarej. Zesz. Nauk. UP Wroc., 568, Roln., 92, 31-35.

Frąszczak, B., Kleiber, T., Klama, J. (2012). Impact of effective microorganisms on yields and nutrition of sweet basil (Ocimum basilicum L.) and microbiological properties of the substrate. Afr. J. Agric. Res., 7, 43, 5756-5765.

Gibczyńska, M., Lewandowska, L. (2005). Porównanie zmian zawartości frakcji fosforu i aktywności fosfatazy w glebie inkubowanej. Inż. Ekol., 13, 64-65.

Górski, R., Kleiber, T. (2010). Effect of Effective Microorganisms (EM) on nutrient contents in substrate and development and yielding of rose (Rosa hybrida) and gerbera (Gerbera jamesonii). Ecol. Chem. Eng. A, 17, 4, 505-513.

Guettes, R., Dott, W., Eisentraeger, A. (2002). Determination of urease activity in soils by carbon dioxide release for ecotoxicological evaluation of contaminated soils. Ecotoxicology, 11, 357-364.

Hoffmann, G., Teicher, K. (1961). Ein kolorimetrisches Verfahren zur Bestimmung der Ureaseaktivität im Boden. Z. Pflanzenernaehr. Dueng. Bodenkd., 95, 55-63.

Janas, R. (2009). Możliwości wykorzystania efektywnych mikroorganizmów w ekologicznych systemach produkcji roślin uprawnych. Probl. Inż. Roln., 3, 111-119.

Janas, R., Grzesik, M. (2011). Możliwości zastosowania wybranych preparatów biologicznych w ekologicznej uprawie roślin prozdrowotnych. J. Res. Appl. Agric. Eng., 56, 3, 152-157.

Januszek, K., Błońska, E., Stanik, P. (2007). Uwagi dotyczące oznaczania aktywności dehydrogenaz w glebach testem TTC - formazan. Acta Agrophys., 9, 3, 635-644.

Kaczmarek, Z., Wolna-Maruwka, A., Jakubus, M. (2008). Zmiany liczebności wybranych grup drobnoustrojów glebowych oraz aktywności enzymatycznej w glebie inokulowanej Efektywnymi Mikroorganizmami (EM). J. Res. Appl. Agric. Eng., 53, 3, 122-127.

Khan, B. M., Hossain, M. K., Mridha, M. A. U. (2006). Effect of microbial inoculants on Albizia saman germination and seedling growth. J. For. Res., 17, 2, 99-102.

Klama, J., Jędryczka, M., Wiśniewska, H., Gajewski, P. (2010). Ocena stopnia rozwoju oraz kondycji fizjologicznej ozimych roślin pszenicy i rzepaku w uprawie z zastosowaniem Efektywnych Mikroorganizmów. Nauka Przyr. Technol., 4, 6, \#81.

Kucharski, J. (1997). Relacje między aktywnością enzymów a żyznością gleby. In: W. Barabasz (ed.), Drobnoustroje w środowisku glebowym. Występowanie, aktywność i znaczenie (pp. 327-348). Kraków: Wyd. AR.

Kucharski, J., Jastrzębska, E. (2005). Rola mikroorganizmów efektywnych (EM) i glebowych w kształtowaniu właściwości mikrobiologicznych gleb. Zesz. Probl. Post. Nauk Roln., 506, $315-322$.

Kucharski, J., Niewolak, T. (1997). Wpływ systemu uprawy roślin zbożowych na aktywność enzymów glebowych. In: W. Barabasz (ed.), Drobnoustroje w środowisku glebowym. Występowanie, aktywność i znaczenie (pp. 349-356). Kraków: Wyd. AR.

Martyniuk, S. (2010). Wytwarzanie preparatów mikrobiologicznych na przykładzie bakterii symbiotycznych roślin motylkowatych. J. Res. Appl. Agric. Eng., 55, 4, 20-23.

Martyniuk, S., Księżak, J. (2011). Ocena pseudomikrobiologicznych biopreparatów stosowanych w uprawie roślin. Pol. J. Agron., 6, 56-64.

Mau, F. P. (2007). Efektywne Mikroorganizmy w domu i ogrodzie dla lepszego wzrostu roślin i dla zdrowia. Mszczonów: Źródło Życia.

Mocek-Płóciniak, A. (2010). Wykorzystanie aktywności enzymatycznej do oceny wpływu antropogenicznych zmian wywołanych przez metale ciężkie w środowisku glebowym. Nauka Przyr. Technol., 4, 6, \#86.

Ott, L. (1984). An introduction to statistical methods and data analysis. Boston: PWS.

Pruszyński, S., Bartkowiak, J., Pruszyński, G. (2012). Integrowana ochrona roślin w zarysie. Poznań: Centrum Doradztwa Rolniczego w Brwinowie Oddział w Poznaniu. 
Wolna-Maruwka, A., Mocek-Płóciniak, A., Schroeter-Zakrzewska, A., Niewiadomska, A., Piechota, T., Swędrzyńska, D., Kosicka, D., Pilarska, A. A. (2015). The influence of a microbial inoculum on the enzymatic activity of peat and morphological features of the French marigold. Nauka Przyr. Technol., 9, 4, \#47. DOI: 10.17306/J.NPT.2015.4.47

Schneider, K., Turrion, M.-B., Grierson, P. F., Gallardo, J. F. (2001). Phosphatase activity, microbial phosphorus, and fine root growth in forest soils in the Sierra de Gata, western central Spain. Biol. Fertil. Soils, 34, 3, 151-155.

Schroeter-Zakrzewska, A., Wolna-Maruwka, A., Borowiak, K. (2013). The application of EM preparation in growing of zonal pelargonium (Pelargonium zonale). Ecol. Chem. Eng. A, 20, $6,701-708$.

Tabatabai, M. A., Bremner, J. M. (1969). Use of p-nitrophenyl phosphate for assays of soil phosphatase activity. Soil Biol. Biochem., 1, 4, 301-307.

Tarafdar, J. C., Rao, A. V. (1990). Effect of manures and fertilizers on dehydrogenase and phosphatase in the rhizosphere of arid crops. J. Soil Sci., 23, 2, 189-193.

Thalmann, A. (1968). Zur Methodik der Bestimmung der Dehydrogenase Aktivität in Boden mittels Triphenyltetrazoliumchlorid (TTC). Landwirtsch. Forsch., 21, 249-258.

Vallance, J., Déniel, F., Le Floch, G., Guérin-Dubrana, L., Blancard, D., Rey, P. (2011). Pathogenic and beneficial microorganisms in soilless cultures. Agron. Sustain. Dev., 31, 1, 191-203.

Wielgosz, E., Dziamba, Sz., Dziamba, J. (2010). Effect of application of EM spraying on the populations and activity of soil microorganisms occurring in the root zone of spring barley. Pol. J. Soil Sci., 43, 1, 65-72.

Wielgosz, E., Szember, A. (2006). Występowanie naturalnych zespołów drobnoustrojów glebowych w strefie przykorzeniowej roślin wykorzystywanych w zagospodarowywaniu terenów przydomowych. Ann. Univ. Mariae Curie-Skłodowska Sect. E, 61, 75-92.

Wolna-Maruwka, A., Schroeter-Zakrzewska, A., Borowiak, K. (2010). Wpływ preparatu EM na stan mikrobiologiczny podłoża przeznaczonego do uprawy pelargonii (Pelargonium $\times$ hortorum). Nauka Przyr. Technol., 4, 6, \#98.

Wolna-Maruwka, A., Schroeter-Zakrzewska, A., Borowiak, K., Niewiadomska, A. (2012). Impact of microbiological inoculum on numbers and activity of microorganisms in peat substrate and on growth and flowering of scarlet sage. Pol. J. Environ. Stud., 21, 6, 357-367.

Wolna-Maruwka, A., Schroeter-Zakrzewska, A., Borowiak, K., Niewiadomska, A. (2014). Analysis of the effect of $\mathrm{BAF}_{1}$ microbial inoculum on microbiological and biochemical condition of peat under scarlet sage cultivation. Fresenius Environ. Bull., 23, 1a, 228-238.

Wyczółkowski, A. I., Dąbek-Szreniawska, M. (2005). Enzymy biorące udział w mineralizacji azotu organicznego. Acta Agrophys. Rozpr. Monogr., 120, 3, 37-61.

Żebrowska, E., Ciereszko, I. (2009). Udział kwaśnych fosfataz w gospodarce fosforanowej komórek roślinnych. Post. Biol. Kom., 36, 4, 1-17.

\section{WPŁYW PREPARATU MIKROBIOLOGICZNEGO NA AKTYWNOŚĆ ENZYMATYCZNĄ TORFU I CECHY MORFOLOGICZNE AKSAMITKI ROZPIERZCHŁEJ}

Streszczenie. Celem przeprowadzonych badań było określenie poziomu aktywności enzymatycznej podłoża w uprawie aksamitki rozpierzchłej po inokulacji preparatem EM. Materiałem do badań było podłoże torfowe o $\mathrm{pH}$ 5,5-6,0, w którym wysadzono rośliny i zaszczepiono różnymi dawkami biopreparatu EM $(1: 10,1: 50,1: 100)$. Próbki podłoży, w których uprawiano rośliny, pobierano w trzech terminach: sadzenia sadzonek, w fazie wzrostu wegetatywnego oraz $\mathrm{w}$ fazie kwitnienia. Zakres badań obejmował oznaczanie metodą spektrofotometryczną poziomu aktywności dehydrogenaz, ureazy i aktywności fosfatazy kwaśnej. Ponadto wykonano analizy morfologiczne takich cech, jak: wysokość rośliny, liczba i długości pędów, liczba pąków i kwiatostanów, a także indeks zazielenienia (SPAD). Na podstawie uzyskanych wyników wykazano, że głównym 
Wolna-Maruwka, A., Mocek-Płóciniak, A., Schroeter-Zakrzewska, A., Niewiadomska, A., Piechota, T., Swędrzyńska, D., Kosicka, D., Pilarska, A. A. (2015). The influence of a microbial inoculum on the enzymatic activity of peat and morphological features of the French marigold. Nauka Przyr. Technol., 9, 4, \#47. DOI: 10.17306/J.NPT.2015.4.47

czynnikiem determinującym poziom aktywności badanych enzymów była faza rozwojowa roślin. Preparat EM korzystnie wpływał na poziom aktywności fosfatazy kwaśnej, nie wykazano natomiast jego stymulującego wpływu na aktywność ureazy czy dehydrogenaz. Dolistne i doglebowe zastosowanie preparatu EM o stężeniu 1:100 przyczyniło się do tworzenia na roślinach większej liczby liści o ciemniejszym zabarwieniu, a także większej liczby kwiatostanów.

Słowa kluczowe: aktywność enzymatyczna, torf, preparat mikrobiologiczny EM, aksamitka rozpierzchła

Corresponding address - Adres do korespondencji:

Agnieszka Wolna-Maruwka, Katedra Mikrobiologii Ogólnej i Środowiskowej, Uniwersytet Przyrodniczyw Poznaniu, ul. Szydtowska 50,60-656 Poznań, Poland, e-mail: amaruwka@interia.pl

Accepted for publication - Zaakceptowano do opublikowania:

25.05.2015

For citation - Do cytowania:

Wolna-Maruwka, A., Mocek-Płóciniak, A., Schroeter-Zakrzewska, A., Niewiadomska, A., Piechota, T., Swędrzyńska, D., Kosicka, D., Pilarska, A. A. (2015). The influence of a microbial inoculum on the enzymatic activity of peat and morphological features of the French marigold. Nauka Przyr. Technol., 9, 4, \#47. DOI: 10.17306/J.NPT.2015.4.47 